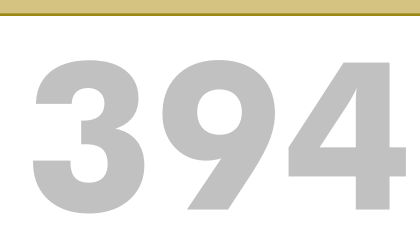

Nove m b r o 2010

AFFINITIES AND AGREEMENTS AMONG MAJOR BRAZILIAN SHAREHOLDERS

Lior Sternberg

Ricardo P. Câmara Leal

Patrícia Maria Bortolon 
Relatórios COPPEAD é uma publicação do Instituto COPPEAD de Administração da Universidade Federal do Rio de Janeiro (UFRJ)

\section{Editor}

Prof. Mauricio Mittelman

\section{Editoração}

Lucilia Silva

\section{Ficha Catalográfica}

Ana Rita Mendonça de Moura

Sternberg, Lior.

Affinities and agreements among major Brazilian shareholders / Lior Sternberg, Ricardo Pereira Câmara Leal e Patrícia Maria Bortolon. - Rio de Janeiro: UFRJ /COPPEAD, 2010.

21 p.; $27 \mathrm{~cm}$. - (Relatórios COPPEAD; 394)

ISBN 978-85-7508-081-8

ISSN 1518-3335

1. Finanças. I. Leal, Ricardo Pereira Câmara.

II. Bortolon, Patrícia Maria. III. Título. IV. Série.

$$
\text { CDD - } 332
$$

\section{Pedidos para Biblioteca:}

Caixa Postal 68514 - Ilha do Fundão

21941-972 - Rio de Janeiro - RJ

Telefone: $21-2598-9837$

Telefax: 21-2598-9835

e-mail: biblioteca@coppead.ufri.br

Site: www.coppead.ufri.br 


\title{
AFFINITIES AND AGREEMENTS AMONG MAJOR BRAZILIAN SHAREHOLDERS
}

\author{
Lior Sternberg * \\ Ricardo P. Câmara Leal ** \\ Patrícia Maria Bortolon ***
}

* Sternberg is Director at Value Representações Estratégicas Ltda, R. do Rosário, 103, Rio de Janeiro, Brazil (Tel. +55 21 88773332,e-mail: sternberglior@gmail.com).

** Leal is the corresponding author and is a Professor of Finance at the COPPEAD Graduate School of Business at the Federal University of Rio de Janeiro (UFRJ), R. Pascoal Lemme, 355, Rio de Janeiro, RJ, 21941 -918, Brazil (Tel. +55 21 2598-9800, e-mail: ricardoleal@coppead.ufri.br) *** Bortolon is an Associate Professor at the Accounting Department at the Federal University of Espírito Santo (UFES), Av. Fernando Ferrari, 514, Campus Goiabeiras, Vitória, ES, 29075-910, Brazil (Tel. +55 27 4009-2602, e-mail: p.m.bortolon@gmail.com). 


\section{ABSTRACT}

Purpose: To provide control and ownership percentages for the three largest shareholders, details on their identity types and affinities, and their participation in formal agreements in Brazilian listed companies.

Design/Methodology/Approach: Direct percentage holdings of voting and non-voting shares computed for 399 listed companies in 2007 according to four listing segments. The three largest direct and ultimate shareholders were classified into nine identity types and as signatories of shareholder agreements.

Findings: The concentration of control rights remains very high but is significantly lower in the most demanding listing segment. There is a great similarity in identity types among the three largest shareholders of a company. Shareholder agreements are common either with or without a controlling shareholder and more frequent with greater control dispersion. The largest shareholder is a signatory in most agreements.

Research Limitations/Implications: The pervasive affinity among the largest shareholders, the ubiquity of shareholder agreements, and the resilient control concentration levels cast doubts about the possible positive effects that more control dispersion and fewer nonvoting shares might had. Any gains from ownership arrangement changes still need to be addressed.

Practical Implications: Investors must be aware that benefits from greater control dispersion may be offset by formal and informal agreements among the largest shareholders.

Originality/Nalue: The sample includes virtually all listed companies, agreements were investigated in all of them, and identity associations were mapped directly and indirectly for the three largest shareholders.

Keywords: Control Concentration, Ownership Concentration, Shareholders Agreements, Shareholder Affiliation.

Paper Type: Research paper. 


\section{1 - INTRODUCTION}

We investigate the control and ownership percentages, the identity, and the formal coalitions among the three largest shareholders of Brazilian listed companies. The control and ownership percentages portray the degree of concentration of the equity capital among the three major shareholders. The similarities in identity types among the three largest shareholders indicate their potential affinity of interests for informal or formal coalitions. Shareholder agreements are hard evidences of such coalitions. Shareholder coalitions may be formed to exercise control effectively and may result in better monitoring of the controlling shareholder. The coalition may inhibit the extraction of private benefits by the largest shareholders, on behalf of the minority shareholders, or may simply lead to their sharing among the coalition members, in detriment of the minority.

Control is very concentrated in Brazil. We report an average direct control concentration of 59 percent for the largest shareholder and of 77 percent for the three largest shareholders jointly in 2007. Even though these percentages are high, they have declined in the last few years. Leal and Carvalhal da Silva (2007) related average direct control concentration of 71 and 89 percent for the largest and the three largest shareholders jointly in 2002, respectively.

Brazilian companies use non-voting shares intensively but their aggregate proportions in the equity capital have decreased since 2004 because many companies unified their shares and migrated to the Novo Mercado listing segment. In addition, most companies that went public after 2004 listed in this new segment of the exchange as well. The Novo Mercado listing segment requires that companies issue only voting shares. The Brazilian corporate law establishes that there is one vote per voting share and does not admit multiple vote common shares. Novo Mercado imposes a number of additional transparency and corporate governance practices, investor protection charter provisions, arbitration for dispute resolution between the company and shareholders, and a minimum liquidity level.

We reveal that control concentration levels are remarkably lower in Novo Mercado compared to the other three less demanding listing levels. We provide more details about all listing levels later. Bortolon (2010) portrays that the number of companies with their equity capital comprised exclusively of voting shares tripled from 2000 (56) to 2008 (163). Yet, Leal $(2011)$ reports that slightly more than 50 percent of them still include non-voting shares in their equity capital. Some of them exhibit very large proportions of non-voting 
shares, and among those are the two larger capitalization companies in Brazil, Petrobras, the state-owned oil giant, which accomplished the largest worldwide public offer of stocks of all times in 2010, and Vale, the second largest mining company in the world and the largest non state-owned company in Latin America, that displayed 42 and 39 percent of non-voting shares in their equity capital on 31 December 2009, respectively.

Brazilian non-voting shares are called "preferred shares" and must offer additional rights stipulated in the law to its owners when they do not grant the right to vote, a condition that has to be established in the charter. Companies usually opt to pay a ten percent higher dividends to non-voting shareholders relative to those of voting shareholders but, sometimes, they concede a mandatory bid right to non-voting shareholders between 80 and 100 percent of the acquisition price paid to controlling shareholders in control transfer dealings. In addition to non-voting shares, Bortolon (2010) demonstrates that 77 percent of her sample of 255 listed companies in 2006 makes use of indirect control structures. Direct control by the largest shareholder is maintained throughout the indirect structure in 24 percent of such companies, is shared in 22 percent of them, and is diluted in four percent of them. Control is gained throughout the indirect structure by multiple large shareholders in 23 percent of the companies and by a single shareholder in four percent of them.

The number of companies with more disperse control in Brazil has grown. The number of companies with more than 50 percent of their shares free floating in the market was around 30 percent of the total of companies in the Novo Mercado and about ten percent of the total of listed companies, according to Capital Aberto magazine (2008). Yet, concentrated control is still the norm in Brazil, as in many emerging markets, and it may be a mixed blessing. Controlling shareholders monitor managers more effectively but may try to extract private benefits at the expense of minority shareholders. There is more variety in Brazilian control patterns now, with some dispersed control companies, many companies with multiple large shareholders, and still a majority of companies with a clear dominant shareholder but that frequently use shareholder agreements, as we will show.

Our results picture a declining concentrated ownership, the prevalence of indirect control structures and the widespread, but declining, use of nonvoting shares. On the other hand, the use of agreements is on the rise which may offset any benefits from dispersion. There is much similarity between the identity types of the largest shareholders, particularly individuals. The affinity among may favor their informal congruence on and above any formal agreements. 
Relative to previous work about Brazilian ownership and control, our contribution is to examine a sample that includes virtually all listed companies, while Leal and Carvalhal da Silva (2007), for instance, reported only from the most liquid firms because they intended to analyze market values as well. We provide details of control and ownership percentages for the three largest shareholders according to four listing levels and the existence or not of a controlling shareholder. Gorga (2009) studied agreements among companies without a controlling shareholder while we investigated agreements in all listed companies and demonstrated that they are also very common in companies with a controlling shareholder. We provide a detailed analysis of the similarities in the identity types of the three largest shareholders, which has not been offered before, to the best of our knowledge. The evidence for Brazil may be representative for other Latin American countries as well as for many emerging markets elsewhere. This paper proceeds with a brief review of the literature, followed by a section about the sample and then our analysis of the results. The final portion of the paper concludes.

\section{2 - LITERATURE REVIEW}

Demsetz and Lehn (1985) find that the five largest shareholders in a sample of 511 US corporations commonly have between ten and 25 percent of ownership concentration. Demsetz and Villalonga (2001) do not observe a relationship between ownership and performance and argue that the profit maximizing interests of shareholders drive their decisions to either concentrate or disperse ownership and, thus, no relationship between firm performance and ownership changes should exist. They also claim that the bulk of previous research supports that managerial ownership and performance are unrelated. Ownership structures assume the configuration that is the most suitable to the market in which firms operate and market values reflect this, leading to no discernable pattern between performance and ownership, which is endogenous. They studied a randomly selected subsample of 223 US firms from the Demsetz and Lehn (1985) sample.

In line with the concept of market dependent configuration, Gomes and Novaes (2005) conceive a model in which shared control is efficient when the financing requirements of the firm are large and it is difficult for outsiders to evaluate investment opportunities, particularly in jurisdictions offering poor investor protection, which may be the case of many emerging markets. The presence of large non-managerial shareholders may inhibit the consumption of private benefits by the major managing shareholder. These additional large shareholders could have the resources and the incentives to monitor the 
largest shareholder. It is also possible that they persuade the major shareholder to share the benefits of control with them. Zwiebel (1995) presents a model in which private benefits of control are divisible and shared among block shareholders who form control coalitions. Bennedsen and Wolfenzon (2000) develop a model for a closely held corporation in which large shareholders would have the motivation to form a coalition large enough to gain control, but not too large not to leave out other shareholders who may be expropriated.

Pergola and Verreault (2009) review the empirical literature about the monitoring role of large shareholders and conclude that their presence may result in benefits shared among all shareholders if they are corporate block holders who are not affiliated with management and not part of a control coalition. The identity, affinity, and formal association among large shareholders may result in either positive or negative effects to minority shareholders. Maury and Pajuste (2005) analyze the effect multiple large shareholders have on the performance of 136 non-financial Finnish firms during between 1993 and 2000. The performance of companies that have families as their controlling and second largest shareholder is worst than when the second largest shareholder is not a family. They conclude that the affinity that may exist when families are the two largest shareholders reduces the marginal cost of extracting control benefits.

Laeven and Levine (2008) find that single controlling shareholder firms make up 50 percent of their European sample, while multiple controlling shareholder firms and dispersed control firms make up 34 and 16 percent of the sample, respectively. Departures from the "one share, one vote" principle may be reflected in the disparity between the control and cash flow rights owned by the largest shareholders. Control rights percentages that are not commensurate to cash flow rights percentages may convey a non trivial likelihood of serious conflicts of interest between major and minority shareholders. The average Tobin's $Q$ is larger for dispersed ownership firms (2.03) and for companies with multiple large shareholders with commensurate cash flow rights (1.94) and lower for single majority shareholder firms (1.61) in Laeven and Levine (2008). The authors conclude that disparities between the holdings of the two largest shareholders harm firm value. Lins (2003) finds that the proportion of control belonging to management is negatively associated with firm value in 18 emerging markets. This relationship is mitigated when other large shareholders exist.

Non-voting shares coupled with indirect control structures may leverage control. Bortolon (2010) estimated the average indirect control concentration of the largest and of the three largest shareholders at 46 and 67 percent, respectively, in 2006. She estimated 
the ratio of the average indirect percentage of voting rights to the average indirect percentage of ownership rights of the largest and of the three largest shareholders to be 1.67 and 1.49, respectively, in 2006. Brazilian controlling shareholders seem to employ non-voting shares to leverage their share of control. Bortolon (2010) also believes that the presence of indirect control structures, in addition to non-voting shares, leverage control even more.

Leal and Carvalhal da Silva (2008) recount that Brazilian companies that employed indirect control structures had a lower market value than those that did not in 2002 but they do not perform a causality analysis. They also give an account that firms with a direct controlling shareholder that does not keep control indirectly have a larger market value than those in which the direct controlling shareholder remains as the ultimate controlling shareholder indirectly. However, the authors do not find that companies with a direct controlling shareholder have a lower market value than those that do not. The positive valuation effects of ownership seem to be associated with the presence of indirect control structures and the dilution of control rights within it. There are more incidences of shareholders agreements when there is a dispersion of control rights in the indirect control structure. The authors report that 22 percent of the firms in their sample of 214 listed companies have shareholders agreements. Gorga (2009) reckoned that 50 percent of her sample of 84 Brazilian firms without a direct controlling shareholder had shareholder agreements.

Leal and Oliveira (2002) noticed the rise in the use of shareholder agreements in Brazil. Gorga (2009) presents a detailed analysis of the clauses in these agreements and discusses their role in the increasing dispersion of ownership in Brazil. She reports that the law lets shareholders agreements regulate the purchase and sales of shares, the preference to acquire shares, and the exercise of voting rights and control. These agreements became more powerful when a corporate law reform in 2001 bound the voting of directors appointed by the their signatories to their will. Gorga (2009) asserts that Brazilian shareholders have strong incentives to disclose these agreements to the company because, if they do not, they cannot enforce it against no-signing parties, such as the directors they appoint. The process of disclosing to the company means that the agreement is added to the public registration records of the company.

It is important to close with a mention of studies that investigated causality between value, performance, corporate governance practices, and control and ownership concentrations. Silveira et al. (2010) conclude that the relationship between corporate governance practices, represented by a practices score, control and ownership 
percentages of the largest shareholders, market value, and accounting performance are endogenous. Leal and Carvalhal da Silva (2007) found no evidence of a relationship between the control and ownership levels and market value with the presence of a corporate governance practices score in a $3 S L S$ model. The Brazilian evidence favors the views presented by some of the authors reviewed of no causal relationship between control and ownership percentages and corporate value and performance and, as a result, we did not pursue this line of investigation.

The literature points out to the importance of the role of large shareholders, their identity, and their associations and formal coalitions. This study will focus on the three largest direct shareholders of Brazilian listed companies.

\section{3 - SAMPLE}

The sample consisted of the 409 Brazilian listed companies at the end of 2007. All information was obtained from their filings with CVM, the Brazilian Securities Commission (Comissão de Valores Mobiliários), at its Internet site. Ten companies did not report shareholdings for the year. The final sample included 399 companies.

We analyze the direct holdings of the three largest shareholders. The company must reveal who are the holders of at least five percent of its voting shares. A list with 856 shareholders (on average 2.14 shareholders per company) includes the three largest shareholders of the 399 companies which own at least five percent of the voting shares. A controlling shareholder is one that owns 50 percent or more of the voting shares.

Shareholders were classified into one of these nine types: individual or families; private companies; public companies; banks (including financial institutions and insurance companies); pension funds; government; foreigners (either individuals or corporations); foundations; and others. The information about the identity of the indirect holders was obtained both from CVM and from the Infoinvest information service. We did not compute indirect holding percentages because they do not change significantly from one year to the next, in addition to being a slow and time consuming process. Indirect holdings for 2006 are reported in Bortolon (2010) and Leal (2011) for 2002 and for previous years in Leal and Carvalhal da Silva (2007) and Aldrighi and Mazzer Neto (2007).

Shareholders agreements in Brazil are common in companies with a controlling shareholder. We examined such agreements in all companies (with and without a 
controlling shareholder) while Gorga (2009) examined only those in companies without a controlling shareholder.

$$
4-\text { RESULTS }
$$

The four listing segments for stocks at BM\&FBovespa (the Brazilian securities, merchandise, and derivatives exchange) are called Traditional, Level 1, Level 2, and Novo Mercado. The Traditional segment was the only one up to the year 2000 and it does not make any additional requirements to what is legally mandated. The other three levels comprise what the exchange calls Differentiated Corporate Governance Levels, created in 2000. Level 1 is the least demanding. Its additional requirements are concerned with more liquidity and transparency, and include additional financial statements, such as a cash flow and consolidated statements, disclosure of details of related party transactions and of company stock and derivatives trading by the controlling shareholders, at least one annual meeting with securities analysts, keeping at least 25 percent of its shares free floating, and to favor public stock issuance methods that lead to greater dispersion. Level 2 encompasses all the requirements in Level 1 and adds a number of mandatory corporate governance practices, such board size of at least five members with a minimum of 20 percent of them independent, submission to arbitration for dispute resolution with shareholders, mandatory bid rights respectively to minority voting and non-voting shareholders of 100 and of 80 percent of the price offered to controlling shareholders in control transfer transactions, and voting rights to non-voting shareholders in corporate restructuring decisions, among other requirements. It also requires the adoption of international accounting standards, which have been required from all public companies in Brazil from 2010. The Novo Mercado encompasses all the requirements of Levels 1 and 2 plus a ban on the issuance of non-voting stocks. Our sampled companies include 246 listed in the Traditional segment (62\%), 93 in the Novo Mercado (23\%), 41 in Level 1 (10\%), and 19 in Level 2 (5\%).

\section{1 Holding patterns of the three largest shareholders}

Table 1 shows the number of companies with and without a controlling shareholder in the different listing segments. In the Novo Mercado, only 32 percent of the companies have a single controlling shareholder while about 75 percent of the companies in the other listing segments have a controlling shareholder. The shareholding of Brazilian companies at the end of 2007 still was very concentrated. Sixty-five percent of all 
companies (260) have a single shareholder with more than 50 percent of the voting capital. The controlling shareholder of these companies averages $77.74 \%$ of the voting capital with a median of $79.57 \%$. Medians, standard deviations, minimum and maximum values of the shareholding percentages are not reported in Table 1 to save space but are available upon request. The largest shareholder of companies without a controlling shareholder (139) averaged $30.48 \%$ of the voting shares, with a median of $29.27 \%$. These figures are similar to those reported for 2002 by Leal and Carvalhal da Silva (2007), whose sample included 214 among the most liquid firms, and by Aldrighi and Mazzer Neto (2007), whose much broader sample of 666 firms included non-listed public companies as well. 
TABLE 1 Descriptive statistics according to listing segment

\begin{tabular}{|c|c|c|c|}
\hline & $\begin{array}{c}\text { Companies with a } \\
\text { controlling } \\
\text { shareholder }\end{array}$ & $\begin{array}{c}\text { Companies without } \\
\text { a controlling } \\
\text { shareholder }\end{array}$ & $\begin{array}{c}\text { All } \\
\text { companies }\end{array}$ \\
\hline \multicolumn{4}{|l|}{ All listing segments: } \\
\hline \# firms & 260 & 139 & 399 \\
\hline \# firms with shareholder agreement & 46 & 55 & 101 \\
\hline \multicolumn{4}{|l|}{ Shareholding averages (\%): } \\
\hline Voting - largest & 77.74 & 30.48 & 61.27 \\
\hline Voting - three largest together & 89.22 & 58.16 & 78.32 \\
\hline Non-voting - largest & 28.25 & 8.47 & 23.34 \\
\hline Non-voting - three largest together & 35.48 & 22.33 & 32.17 \\
\hline All shares - largest & 63.37 & 25.92 & 50.33 \\
\hline All shares - three largest together & 73.26 & 49.87 & 65.05 \\
\hline \multicolumn{4}{|l|}{ Novo Mercado (admits voting shares only): } \\
\hline \# firms & 30 & 63 & 93 \\
\hline \# firms with shareholder agreement & 7 & 31 & 38 \\
\hline \multicolumn{4}{|l|}{ Shareholding averages (\%): } \\
\hline Voting - largest & 59.48 & 27.18 & 37.60 \\
\hline Voting $-2^{\text {nd }}$ largest & 8.88 & 13.92 & 12.66 \\
\hline Voting - $3^{\text {rd }}$ largest & 6.84 & 9.23 & 8.88 \\
\hline \multicolumn{4}{|l|}{ Level 1: } \\
\hline \# firms & 31 & 10 & 41 \\
\hline \# firms with shareholder agreement & 7 & 7 & 14 \\
\hline \multicolumn{4}{|l|}{ Shareholding averages (\%): } \\
\hline Voting - largest & 73.18 & 32.39 & 63.23 \\
\hline Voting $-2^{\text {nd }}$ largest & 19.32 & 19.76 & 19.46 \\
\hline Voting $-3^{\text {rd }}$ largest & 8.64 & 13.46 & 10.67 \\
\hline Non-voting - largest & 11.77 & 0.93 & 9.12 \\
\hline Non-voting $-2^{\text {nd }}$ largest & 9.81 & 5.09 & 8.34 \\
\hline Non-voting - $3^{\text {rd }}$ largest & 5.88 & 0.66 & 3.68 \\
\hline All shares - largest & 40.06 & 16.50 & 34.32 \\
\hline All shares $-2^{\text {nd }}$ largest & 14.83 & 12.58 & 14.12 \\
\hline All shares $-3^{\text {rd }}$ largest & 6.72 & 7.44 & 7.03 \\
\hline \multicolumn{4}{|l|}{ Level 2: } \\
\hline \# firms & 14 & 5 & 19 \\
\hline \# firms with shareholder agreement & 7 & 4 & 11 \\
\hline \multicolumn{4}{|l|}{ Shareholding averages (\%): } \\
\hline Voting - largest & 78.21 & 37.78 & 67.57 \\
\hline Voting $-2^{\text {nd }}$ largest & 17.45 & 17.41 & 17.44 \\
\hline Voting - $3^{\text {rd }}$ largest & 9.33 & 9.47 & 9.42 \\
\hline Non-voting - largest & 24.11 & 4.94 & 19.07 \\
\hline Non-voting $-2^{\text {nd }}$ largest & 7.97 & 20.94 & 12.60 \\
\hline Non-voting - $3^{\text {rd }}$ largest & 0.37 & 0.02 & 0.16 \\
\hline All shares - largest & 51.96 & 22.22 & 44.13 \\
\hline All shares $-2^{\text {nd }}$ largest & 11.47 & 14.39 & 12.51 \\
\hline All shares $-3^{\text {rd }}$ largest & 4.23 & 4.87 & 4.63 \\
\hline \multicolumn{4}{|l|}{ Traditional: } \\
\hline \# firms & 185 & 61 & 246 \\
\hline \# firms with shareholder agreement & 25 & 13 & 38 \\
\hline \multicolumn{4}{|l|}{ Shareholding averages (\%): } \\
\hline Voting - largest & 81.42 & 32.98 & 69.41 \\
\hline Voting $-2^{\text {nd }}$ largest & 18.54 & 22.89 & 20.20 \\
\hline Voting - $3^{\text {rd }}$ largest & 8.65 & 13.93 & 11.66 \\
\hline Non-voting - largest & 31.33 & 10.00 & 26.04 \\
\hline Non-voting $-2^{\text {nd }}$ largest & 11.03 & 8.28 & 9.98 \\
\hline Non-voting $-3^{\text {rd }}$ largest & 8.87 & 6.51 & 7.53 \\
\hline All shares - largest & 68.77 & 26.47 & 58.28 \\
\hline All shares $-2^{\text {nd }}$ largest & 15.97 & 18.56 & 16.96 \\
\hline All shares $-3^{\text {rd }}$ largest & 9.28 & 11.63 & 10.62 \\
\hline
\end{tabular}


Shareholding concentration patterns, however, are not the same for all listing segments. Table 1 provides a detailed description of the shareholding percentages in the four listing segments, showing the voting and cash-flow rights (voting plus non-voting shares) proportions of each one of the three largest shareholders. The Novo Mercado has the second largest number of issues at the exchange (93) and is characterized by a relatively low concentration of control. The largest shareholder in the companies with a controlling shareholder holds on average $59.48 \%$ of the voting rights, which are identical to his cash flow rights due to the "one share, one vote" in this listing segment. The largest shareholder in companies with no controlling shareholder holds on average only $27.18 \%$ of the voting rights. This segment is also characterized by a low number of companies in which there is a controlling shareholder (only 30 out of 93). These numbers are considerably lower than in the other listing segments.

The holdings of the three largest shareholders in Level 1 are much different than those in Novo Mercado. Forty one companies are listed in this segment and the largest shareholder in companies with a controlling shareholder (31 companies) holds on average $73.18 \%$ of the voting capital. The second and third shareholders hold, on average, $19.32 \%$ and $8.64 \%$, respectively. In companies with no controlling shareholders (10 companies) the voting capital proportions of the first, second and third largest shareholders are $32.39 \%, 19.76 \%$ and $13.46 \%$, respectively. The average voting capital percentage held by the second and third largest shareholders is not greatly affected by the presence of a controlling shareholder. The results for Level 2 are very similar.

The percentage of non-voting shares held by the largest shareholders are much smaller, specially for the largest shareholder. The largest shareholder holds six times less non-voting shares than voting shares in companies they control. Nevertheless, they still hold the largest average percentage of non-voting shares. In companies with no controlling shareholder, there is no such pattern and the average holding of non-voting shares by the largest shareholder is miniscule. The pattern of lower percentages of nonvoting shares relative to the percentages of voting shares held by the second and third largest shareholder is similar, but the drop in average percentages may be less abrupt. One possible explanation could be that the largest shareholder is also interested in a larger share of cash-flow rights or, maybe even more plausible, because non-voting shares may be more liquid than the voting shares in the control block, the controlling shareholder wants the ability to trade in the company's stock without changing his/her control proportions. This pattern is somewhat the same in Level 2 . 
The Traditional segment consists of companies that did not migrate to the more demanding listing levels and is the largest in terms of the number of companies (246) and the one that showed the highest concentration of control levels. Table 1 shows that the largest shareholder in companies with a controlling shareholder (185) holds on average $81.42 \%$ of the voting capital. The second and third shareholders hold on average $18.54 \%$ and $8.65 \%$, respectively. The three major shareholders in companies with no controlling shareholders (61) hold on average $32.98 \%, 22.89 \%$ and $13.93 \%$ of the voting capital, respectively. In companies with a controlling shareholder, the three largest shareholders hold on average $31.33 \%, 11.03 \%$ and $8.87 \%$ of the non-voting capital, respectively. They hold $10.00 \%, 8.28 \%$ and $6.51 \%$ of the non-voting shares, respectively, in companies with no controlling shareholder. The percentages of non-voting shares held by the largest shareholder seem to be higher in the Traditional level. It is well-known that most companies in this segment display very low liquidity. On the other hand, one could argue that the relatively high holdings of non-voting shares by the largest shareholder may partially align his or her interests with those in the minority.

We perform pair wise comparisons of the average holdings of the three largest shareholders in each listing segment. We use both the parametrical t-test as well as the non-parametrical Mann-Whitney-Wilcoxon rank test. The holding percentages of voting shares by the largest shareholder is significantly lower in the Novo Mercado than in the other segments for both tests at the one percent level. The results are qualitatively the same for the second and third largest shareholders, between Novo Mercado and the Level 1 and Traditional segments, with slightly lower significance, but there was no significant difference relative to Level 2. There were no differences in means between the other segments. The detailed mean difference tests are available upon request.

\subsection{Relationship between shareholders}

Shareholders of the same type may create unwritten covenants among themselves more easily because of their affinity. The 856 direct shareholders were classified into the 9 types presented in Table 2. Most are private companies (41.59\%), which is consistent with the widespread use of indirect control structures in Brazil. Individuals are the second most common type of shareholder and comprise 17.64 percent of them. Foreigners, individuals or companies, no distinction is possible from the data, are 14.02 percent of the direct shareholders. 
TABLE 2 Number and percentage of shareholders according to their identity type

\begin{tabular}{|ccccccccc|}
\hline Type & $\begin{array}{c}\text { Largest } \\
\text { Shareholder }\end{array}$ & $\begin{array}{c}\text { \% of } \\
\text { Largest }\end{array}$ & $\begin{array}{c}\text { Second } \\
\text { Largest } \\
\text { Shareholder }\end{array}$ & $\begin{array}{c}\text { \% of } \\
\text { Second } \\
\text { Largest }\end{array}$ & $\begin{array}{c}\text { Third Largest } \\
\text { Shareholder }\end{array}$ & $\begin{array}{c}\text { \% of } \\
\text { Third } \\
\text { Largest }\end{array}$ & Total & $\begin{array}{c}\text { \% of } \\
\text { total }\end{array}$ \\
\hline Private Co. & 209 & 52,38 & 88 & 32,00 & 59 & 32,42 & 356 & 41,59 \\
\hline Individual & 48 & 12,03 & 55 & 20,00 & 48 & 26,37 & 151 & 17,64 \\
\hline Foreigner & 43 & 10,78 & 46 & 16,73 & 31 & 17,03 & 120 & 14,02 \\
\hline Public Co. & 40 & 10,03 & 13 & 4,73 & 5 & 2,75 & 58 & 6,78 \\
\hline Bank & 25 & 6,27 & 43 & 15,64 & 22 & 12,09 & 90 & 10,51 \\
\hline Government & 24 & 6,02 & 3 & 1,09 & 0 & 0,00 & 27 & 3,15 \\
\hline Pension Fd. & 5 & 1,25 & 17 & 6,18 & 13 & 7,14 & 35 & 4,09 \\
\hline Others & 4 & 1,00 & 3 & 1,09 & 2 & 1,10 & 9 & 1,05 \\
\hline Foundation & 1 & 0,25 & 7 & 2,55 & 2 & 1,10 & 10 & 1,17 \\
\hline Total & 399 & 100 & 275 & 100 & 182 & 100 & 856 & 100 \\
\hline
\end{tabular}

Private companies, individuals, and foreigners together comprise $73.25 \%$ of the total number of shareholders. We identified the type of the second largest shareholder when the identity type of the largest shareholder is one of these three. The results are in Table 3. The number of firms in which private companies are the largest shareholder falls from 209 in Table 2 to 149 in Table 3 because there was no second largest shareholder with more than the five percent disclosure threshold in 60 companies. In 65 out of these 149 companies (43.72\%) the second largest direct shareholder was a private company as well. The largest group of second largest indirect shareholders is individuals (35.57\%), private companies (18.12\%), foreigners (18.79\%), and banks (14.77\%) when the largest direct shareholder was a private company. The private companies that remained at the end of the indirect ownership chain are limited capital companies whose owners could not be identified. 
TABLE 3 Second largest shareholder given the identity type of the largest shareholder

\begin{tabular}{cccccc} 
& & \multicolumn{2}{c}{ Direct Holding } & \multicolumn{2}{c}{ Indirect holding } \\
Second Largest & Type & No. & $\%$ & No. & $\%$ \\
\hline Shareholder & Private Co. & 65 & 43,62 & 27 & 18,12 \\
& Foreigner & 26 & 17,45 & 28 & 18,79 \\
& Bank & 22 & 14,77 & 22 & 14,77 \\
When the largest is a & Individual & 17 & 11,41 & 53 & 35,57 \\
private company (149) & Pension Fd. & 7 & 4,70 & 7 & 4,70 \\
& Foundation & 4 & 2,68 & 4 & 2,68 \\
& Public Co. & 4 & 2,68 & 4 & 2,68 \\
& Others & 3 & 2,01 & 3 & 2,01 \\
& Government & 1 & 0,67 & 1 & 0,67 \\
& & & & & \\
When the largest is an & Individual & 26 & 60,47 & 33 & 76,74 \\
individual (43) & Private Co. & 9 & 20,93 & 2 & 4,65 \\
& Foreigner & 4 & 9,30 & 4 & 9,30 \\
& Foundation & 2 & 4,65 & 2 & 4,65 \\
& Bank & 1 & 2,33 & 1 & 2,33 \\
& Pension Fd. & 1 & 2,33 & 1 & 2,33 \\
& & & & & \\
& Foreigner & 14 & 42,42 & 15 & 45,45 \\
& Individual & 6 & 18,18 & 9 & 27,27 \\
When the largest is a & Private Co. & 6 & 18,18 & 2 & 6,06 \\
foreigner (33) & Bank & 3 & 9,09 & 3 & 9,09 \\
& Public Co. & 2 & 6,06 & 2 & 6,06 \\
& Pension Fd. & 1 & 3,03 & 1 & 3,03 \\
& Foundation & 1 & 3,03 & 1 & 3,03 \\
\hline
\end{tabular}

Nearly all companies with an individual as the largest direct shareholder had a second shareholder with more than the five percent disclosure threshold (43 out of 48 companies). This group showed the largest similarity between the largest and the second largest shareholder type. Twenty-six out of 43 companies had a second largest direct shareholder who was also an individual. Thirty-three companies exhibited individuals as the second largest indirect shareholder (76.74\%). When the largest direct shareholder was foreign (33 companies), 42.42 percent of the second largest direct and 45.45 of the second largest indirect shareholders were also foreigners.

Table 4 portrays all types of shareholders and the joint similarities between the two and three largest. Out of the 399 companies in the sample, 275 had at least two and 182 had at least three large shareholders with holdings greater than the five percent threshold. In 119 companies the two largest direct shareholders were of the same kind. The two largest indirect shareholders are of the same type in 139 companies (50.55\%). In 49 companies the three largest direct shareholders are of the same type. In 61 companies the 
LEAL, R. P. C.; Carvalhal da Silva, A. L. Controle compartilhado e o valor das empresas brasileiras, RAC-Eletrônica, v. 2, n. 2, p. 296-310, 2008.

LEAL, R. P. C.; Oliveira, C. L. T. de. An evaluation of board practices in Brazil. Corporate Governance - International Journal of Business in Society, v. 2, n. 3, p. 21-25, 2002.

LEAL, R. P. C. The emergence of a serious contender - corporate governance in Brazil, In: MALLIN, C. (ed.), Handbook on international corporate governance - country analyses. 2nd. ed. Cheltenham, UK: Edward Elgar Publishing, 2001. forthcoming.

LINS, K. Equity ownership and firm value in emerging markets. Journal of Financial and Quantitative Analysis, v. 38, n. 1, p. 159-184, 2003.

MAURY, B.; PAJUSTE, A. Multiple large shareholders and firm value. Journal of Banking \& Finance, v. 29, n. 7, p. 1813-1834, 2005.

PERGOLA, T. M.; VERREAULT, D. A. Motivations and potential monitoring effects of large shareholders. Corporate Governance - International Journal of Business in Society, v. 9, n. 5, p 551-563, 2009.

Silveira, A. M. da; Leal, R. P. C.; Carvalhal da Silva, A. L.; Barros, L. A. B. C. Endogeneity of Brazilian corporate governance quality determinants. Corporate Governance - The International Journal of Business in Society, v. 10, n. 2, p. 191-202, 2010.

ZWIEBEL, J. Block investment and partial benefits of corporate control. Review of Economic Studies, v. 62, n. 2, p. 161-185,1995. 
three largest indirect shareholders are of the same type. Private companies and individuals accounted for most similarities. The data in Tables 3 and 4 reveal a large coincidence of shareholder types between the three largest direct and indirect shareholders, which could lead to greater affinity between them, relative to other shareholders, and to the easier formation of informal coalitions with similar interests.

TABLE 4 Identity type similarities between the three largest shareholders

\begin{tabular}{|c|c|c|c|c|c|c|c|c|}
\hline \multirow[b]{3}{*}{ Type } & \multicolumn{4}{|c|}{$\begin{array}{l}\text { Number of companies with the } 1^{\text {st }} \text { and } 2^{\text {nd }} \\
\text { largest shareholders of the same type }\end{array}$} & \multicolumn{4}{|c|}{$\begin{array}{l}\text { Number of companies with the } 1^{\text {st }}, 2^{\text {nd }} \text {, and } 3^{\text {rr }} \\
\text { largest shareholders of the same type }\end{array}$} \\
\hline & \multicolumn{2}{|c|}{ Direct Holding } & \multicolumn{2}{|c|}{ Indirect Holding } & \multicolumn{2}{|c|}{ Direct Holding } & \multicolumn{2}{|c|}{ Indirect Holding } \\
\hline & No. & $\%$ of 275 & No. & $\%$ of 275 & No. & $\%$ of 182 & No. & $\%$ of 182 \\
\hline Private Co. & 65 & 23,64 & 30 & 10,91 & 24 & 13,19 & 4 & 2,20 \\
\hline Individual & 26 & 9,45 & 76 & 27,64 & 15 & 8,24 & 45 & 24,73 \\
\hline Foreigner & 14 & 5,09 & 18 & 6,55 & 6 & 3,30 & 8 & 4,40 \\
\hline Bank & 5 & 1,82 & 5 & 2,18 & 2 & 1,10 & 2 & 1,10 \\
\hline Public Co. & 5 & 1,82 & 6 & 1,82 & 1 & 0,55 & 1 & 0,55 \\
\hline Government & 2 & 0,73 & 2 & 0,73 & 0 & 0,00 & 0 & 0,00 \\
\hline Pension Fd. & 2 & 0,73 & 2 & 0,73 & 1 & 0,55 & 1 & 0,55 \\
\hline Total & 119 & 43,27 & 139 & 50,55 & 49 & 26,92 & 61 & 33,52 \\
\hline
\end{tabular}

Notes: (1) out of the 275 companies with at least two large shareholders with $5 \%$ or more of shareholding; (2) out of the 182 companies with at least three large shareholders with $5 \%$ or more of shareholding.

\subsection{Shareholders agreements}

Shareholders agreements formally define the relationship among its signatories. It can, for example, assign veto power to a shareholder or determine that some (or all) shareholders will vote alike on certain issues. Gorga (2009) asserts that shareholders agreements have become an important and common corporate governance device in Brazil.

Table 1 shows the number of valid shareholders agreements according to the listing segments and the existence of a controlling shareholder. Twenty-five percent (101) of the 399 sampled companies had agreements by the end of 2007. Fifty-five percent of the agreements involve shareholders of companies without a controlling shareholder. Fortyfive percent of the agreements appeared in companies with a controlling shareholder, suggesting that formal coalitions are important for the largest shareholders too. As stated by Gomes and Novaes (2005), shared control is efficient when the financing requirements of the firm are large, when outsiders cannot evaluate investment opportunities easily, and investor protection is inadequate. Considering that there were 189 companies with three 
shareholders owning more than five percent of the voting shares, observing 101 companies with agreements is significant.

The relative occurrence of shareholders agreements is greater for companies with no controlling shareholders listed in the Novo Mercado. The count of agreements is the same in the Novo Mercado and Traditional lists (38). However, in the Novo Mercado most of the agreements are found in companies without a controlling shareholder while this is just the opposite in the Traditional segment. There are relatively fewer companies without a controlling shareholder in the Traditional listing segment and the incidence of agreements is about half of that in the Novo Mercado.

Table 5 pictures the participation of the three largest shareholders in such agreements and shows that the largest shareholder took part in $87.13 \%$ of them, while almost 30\% involved the three major shareholders together. In all but one of the 55 agreements in companies with no controlling shareholder, at least one of the three largest shareholders took part of the agreement. The second and third largest shareholders rarely take part of an agreement without the largest one. In fact, we did not find a single agreement with the presence of the next two largest shareholders without the largest one. Our results suggest that shareholders display strong affinities and establish formal coalitions in most of the companies where there are two or three large shareholders and this almost certainly attenuates any positive effects of the dispersion of control. The virtual non-existence of agreements without the largest shareholders suggests that they are not an obvious instrument to monitor the largest shareholder but a means to join him or her in the exercise of control.

TABLE 5 Participation of the three largest shareholders in agreements

\begin{tabular}{ccccccc} 
Shareholders & $\begin{array}{l}\text { Companies } \\
\text { Without a } \\
\text { Controlling } \\
\text { Shareholder }\end{array}$ & $\%$ & $\begin{array}{l}\text { Companies } \\
\text { With a } \\
\text { Controlling } \\
\text { Shareholder }\end{array}$ & $\%$ & $\begin{array}{c}\text { All } \\
\text { Agreements }\end{array}$ & $\%$ \\
\hline $1+2+3$ & 22 & 40,00 & 8 & 17,39 & 30 & 29,70 \\
$1+(2$ or 3) & 16 & 29,09 & 13 & 28,26 & 29 & 28,71 \\
$1+$ others & 13 & 23,64 & 16 & 34,78 & 29 & 28,71 \\
$2+3$ without 1 & 0 & 0,00 & 0 & 0,00 & 0 & 0,00 \\
2 or 3 without 1 & 3 & 5,45 & 2 & 4,35 & 5 & 4,95 \\
Without 1, 2 and 3 & 1 & 1,82 & 7 & 15,22 & 8 & 7,92 \\
\hline Total & 55 & 100,00 & 46 & 100,00 & 101 & 100,00 \\
\hline
\end{tabular}




\section{5 - CONCLUSIONS}

We examined the direct and indirect control percentages of the three largest shareholders of Brazilian listed companies in 2007 and mapped their potential affinities by means of the similarities of their identity types and of the incidence of agreements between them. Affinities may help the formation of formal or information coalitions with converging interests. These coalitions may align the largest shareholders in detriment of the interests of the minority.

Overall control concentrations remain very high but are significantly lower in the Novo Mercado listing segment, the most demanding in the Brazilian exchange. Two thirds of the companies still possess a controlling shareholder with more than 50 percent of the votes and the average percentage of the voting rights of the largest shareholder is $61.27 \%$. The Novo Mercado does not allow non-voting shares, which were predominant in the exchange until a few years ago. Controlling shareholders in the other listing segments, particularly in the least demanding of them, even now hold a large proportion of non-voting shares, maybe to be able to trade without affecting their grip on control.

There is a considerable potential for non-contractual covenants among shareholders. Informal agreements are likely among shareholders of the same identity type. Private companies, individuals, and foreigners are the most common types of shareholders. The analysis showed a very high incidence of shareholder similarity between the largest and the second largest shareholders. In about half of the companies the two largest indirect shareholders are of the same kind and in about one third of them the three largest shareholders are of the same type.

In more than half of the companies with more than three large shareholders there is a shareholders agreement. The largest shareholder takes part of them in the vast majority of cases and in no case the second and third largest shareholders jointly took part of an agreement without the largest shareholder. This suggests that the second and third largest shareholder join the largest one in the carrying out of control but do not use agreements among themselves to monitor the largest shareholder as a dissention. The greatest relative frequency of agreements was in the Novo Mercado, where there is significantly more dispersion of control rights, but we revealed that 45 percent of the agreements were in companies with a controlling shareholder. The resilient concentration of control levels, the rife potential affinities among shareholders, and the widespread incidence of shareholder 
agreements, particularly in the Novo Mercado, cast doubts about the any positive impacts that control dispersion might have had on minority shareholders.

\section{6 - REFERENCES}

ALDRIGHI, D. M.; MAZZER Neto, R. Evidências sobre as estruturas de propriedade de capital e de voto das empresas de capital aberto no Brasil, Revista Brasileira de Economia, v. 61, n. 2, p. 129-152, 2007.

BENNEDSEN, M.; WOLFENZON, D. The balance of power in closely held corporations. Journal of Financial Economics, v. 58, n. 1-2, p. 113-139, 2000.

BORTOLON, P. M. Determinantes e conseqüências das decisões de estrutura de propriedade: estrutura piramidal e unificação de ações, Tese de doutorado, Instituto COPPEAD de Administração, Universidade Federal do Rio de Janeiro. Rio de Janeiro, 2010.

DEMSETZ, H.; Lehn, K. The structure of corporate ownership: causes and consequences. Journal of Political Economy, v. 93, n. 6, p. 1155-1177, 1985.

DEMSETZ, H.; VILLALONGA, B. Ownership structure and corporate performance. Journal of Corporate Finance, v. 7, n. 3, p. 209-233, 2001.

GOMES, A. R.; NOVAES, W. Sharing of control as a corporate governance mechanism. PIER Working Paper No. 01-029, University of Pennsylvania Institute for Law \& Economic Research, University of Pennsylvania, Philadelphia, February, 2005. Available at: <http://ssrn.com/abstract=277111>. Accessed on September 28, 2010.

GORGA, E. C. R. Changing the paradigm of stock ownership from concentrated towards dispersed ownership? Evidence from Brazil and consequences for emerging countries. Northwestern Journal of International Law \& Business, v. 29, n. 1- 3, p. 439-554, 2009.

LAEVEN, L.; LEVINE, R. Complex ownership structures and corporate valuations. The Review of Financial Studies, v. 21, n. 2, p. 579-604, 2008.

Leal, R. P. C.; Carvalhal da Silva, A. L. Corporate governance and value in Brazil (and in Chile). In: CHONG, A., LOPEZ-DE-SILANES, F. (eds.), Investor protection and corporate governance - firm level evidence across Latin America. Palo Alto, CA.: Stanford University Press, 2007. p. 213-287. 
